\section{DISTRIBUTION AND CONSERVATION STATUS OF CROTON SCABIOSUS BEDD. (EUPHORBIACEAE), AN ENDEMIC TREE SPECIES OF SOUTHERN EASTERN GHATS OF ANDHRA PRADESH, INDIA}

\author{
Sugali Salamma ${ }^{1} \&$ Boyina Ravi Prasad Rao ${ }^{2}$ \\ 1,2 Sri Krishnadevaraya University, Anantapuram, Andhra Pradesh 515003, India \\ ${ }^{1}$ sshailajapr.001@gmail.com, ${ }^{2}$ biodiversityravi@gmail.com (corresponding author)
}

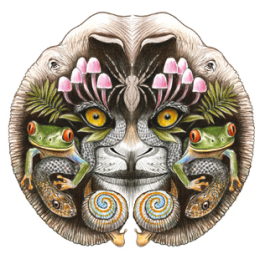

ISSN

Online 0974-7907 Print 0974-7893
Abstract: Croton scabiosus Bedd. (Euphorbiaceae), a tree species, endemic to the southern Eastern Ghats of Andhra Pradesh is presented with its current distribution pattern and assessed in terms of the IUCN Red List status. New data available from field surveys indicate the species status as 'Vulnerable'.

Keywords: Conservation status, Croton scabiosus, distribution, IUCN Red List, Vulnerable.

According to all scenarios analyzed in Global Biodiversity Outlook 3 (Secretariat of the Convention on Biological Diversity 2010), unabated species extinctions at an alarming rate, degradation of habitats and depleting levels of distribution and abundance of species are projected throughout this century. Habitat loss and fragmentation lead to the formation of small, isolated and scattered populations which are increasingly vulnerable to inbreeding depression, high infant mortality and susceptible to environmental stochasticity and consequently possible extinction (Caro 1998). Climate change is expected to influence the viability of populations in future and hence rapid and accurate information on current status of biodiversity at species and ecosystem level is of paramount importance.

Trees, the dominant life form of the tropical forests possess ecological importance as they provide habitat for a wide range of other life forms and their benefits to humanity are multifarious. Continued decline or loss of endemic tree populations can have a major impact on
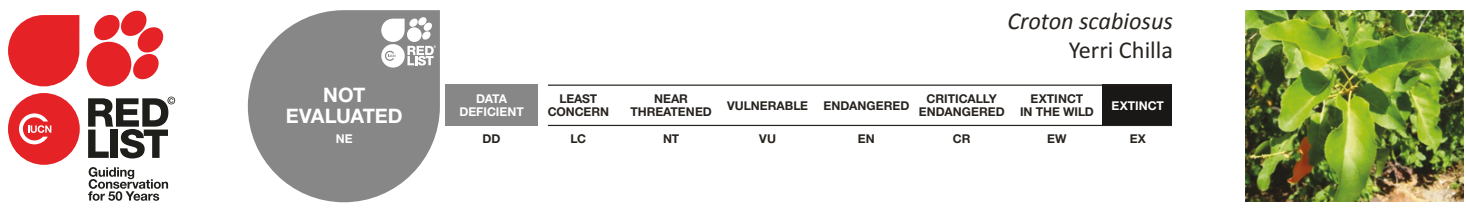

DOI: http://dx.doi.org/10.11609/JoTT.04060.6363-70

Editor: N.P. Balakrishnan, Ret. Joint Director, BSI, Coimbatore, India.

Date of publication: 26 September 2014 (online \& print)

Manuscript details: Ms \# 04060 | Received 13 June 2014 | Final received 09 August 2014 | Finally accepted 04 September 2014

Citation: Salamma, S. \& B.R.P. Rao (2014). Distribution and conservation status of Croton scabiosus Bedd. (Euphorbiaceae), an endemic tree species of southern Eastern Ghats of Andhra Pradesh, India. Journal of Threatened Taxa 6(10): 6363-6370; http://dx.doi.org/10.11609/JoTT.04060.6363-70

Copyright: @ Salamma \& Rao 2014. Creative Commons Attribution 4.0 International License. JoTT allows unrestricted use of this article in any medium, reproduction and distribution by providing adequate credit to the authors and the source of publication.

Funding: First author is grateful to Department of Science and Technology (DST), Govt. of India for providing financial assistance under 'INSPIRE' Program (IF-110360) to carry out this study and senior author acknowledges the financial assistance from Department of Biotechnology, Govt. of India ((BT/PR6603/ NDB/51/089/2005).

Competing Interest: The authors declare no competing interests.

Acknowledgements: Thanks are due to Prof. K.N. Ganeshaiah, University of Agricultural Sciences, Bengaluru and Dr. P.V. Prasanna, Scientist E, Botanical Survey of India, Hyderabad for critical comments on our work. Thanks are also due to Dr. Kiranchand, NRSC, Hyderabad for kind help and Dr. A. Narayanaswamy, Dr. D. Veeranjaneyulu, Mr. M. Chennakesavulu Naik and Mr. Sreenivasulu for their help and cooperation in field work.

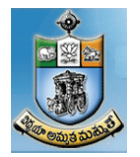


the local forest structure. Small trees especially in arid and semi arid forest habitats have critical role at local and regional level in forest conservation and management; carbon sequestration and consequently climate change. Conservation of small trees is indispensable for sound maintenance of forests (Hagihara et al. 2008).

Most of the floristic databases lack crucial data pertaining to distribution and conservation status of endemic and threatened species of India and the data for many species are just carried forward from past works without doing intensive field work. Very few studies have been published on population numbers and conservation status of Indian endemic plant species. Information in Red Data Books of India (Nayar \& Sastry 1987, 1990; Rao et al. 2003) are, in most cases, based on secondary data and has become outdated as new information is available pertaining to distribution pattern of endemic plants. In the latest Red List (IUCN 2014) IUCN evaluated six plant species as Extinct, 61 Critically Endangered, 151 Endangered and 120 Vulnerable in India.

Regarding fine-scale data on the distribution of species is a very time consuming process (Ahrends et al. 2011). Umashaanker et al. (1998) have developed a method of preparing resource maps for plant species by projecting the transect data into the entire grid. Rao et al. (2010, 2011, 2012) developed distribution maps and evaluated conservation status for three threatened plant species, Cycas beddomei Dyer, Hildegardia populifolia Schott \& Endl. and Dendrobium tenuicaule Hook.f. through satellite imagery based stratified grids and extrapolation of individual numbers.

Estimation of quantitative data based on field observations and extrapolation of population numbers is essential to provide a better understanding of the conservation status of threatened species. The precise evaluation of the conservation status of the concerned taxon is considered to be the most important step in order to successfully prevent its extinction (Vischi et al. 2004). An efficient system for identifying those species that are at risk of extinction could help to achieve this goal in a timeframe sensitive to today's conservation needs (Miller et al. 2013). The IUCN-SSC provides an objective evidence-based system for classifying species in terms of risk of extinction. The latest IUCN Red List Categories Version 3.1 (IUCN 2001) is widely applied for reviewing the conservation status of the species and the sampling methodology in version 11.0 (IUCN Standards and Petitions Subcommittee 2014) provide detailed information on quantitative criteria for determining the threatened categories.
With this background the present work was carried out to assess the distribution and conservation status of Croton scabiosus Bedd. (Euphorbiaceae) (Image 1). Croton scabiosus is a small tree growing up to $7 \mathrm{~m}$ high and locally known as Purugu Chekka, Verri Chilla, Yerri Chilla. The species is found with scattered distribution in open dry deciduous forests of southern Andhra Pradesh in Anantapuram, Kadapa and Nellore districts.

\section{MATERIALS AND METHODS \\ Study of distribution pattern of the species}

In the present study, distribution of Croton scabiosus has been studied based on published reports of its occurrence in the Eastern Ghats and the southern Western Ghats as well as our field studies. There is a 'confusion' over its type locality, Nallamalais. Hence starting from its discovery by R.H. Beddome in 1872, references pertaining to its historic collections and publications were scrutinized. For all the areas of past collections and those reported as additions for species distributions in the present study, representative specimens were collected and deposited in the university herbarium. Preliminary findings of species occurrence in the forests of three districts in Andhra Pradesh: Anantapuram, Kadapa and Nellore and reports of its occurrence in the Kurnool and Chittoor District adjoining Kadapa District, the whole southern Andhra Pradesh region has been thoroughly explored (Image 2). Field data of our research team pertaining to floristic inventories covering southern Andhra Pradesh for the past 20 years through 10 research projects was also taken into consideration while studying the distribution of the species.

Intensive explorations in the study area has resulted in the identification of 15 localities for the species which are grouped into eight locations (or subpopulations) based on threat factors following IUCN methodology (IUCN 2001). A 'location' is defined accordingly, a geographically or ecologically distinct area in which a single threatening event can rapidly affect all individuals of the taxon present and the size of the location depends on the area covered by the threatening event and may include part of one or many subpopulations (IUCN 2001; IUCN Standards and Petitions Subcommittee 2014). In Croton scabiosus habitats, fire and seed borne pathogens are seen as serious threats to the population.

All the 15 localities were sampled through 75 transects of $1000 \times 5 \mathrm{~m}$ size; each locality with five transects is defined as one cluster and are identified based on the geographical separation from other clusters. Thus, 15 clusters were further grouped into 


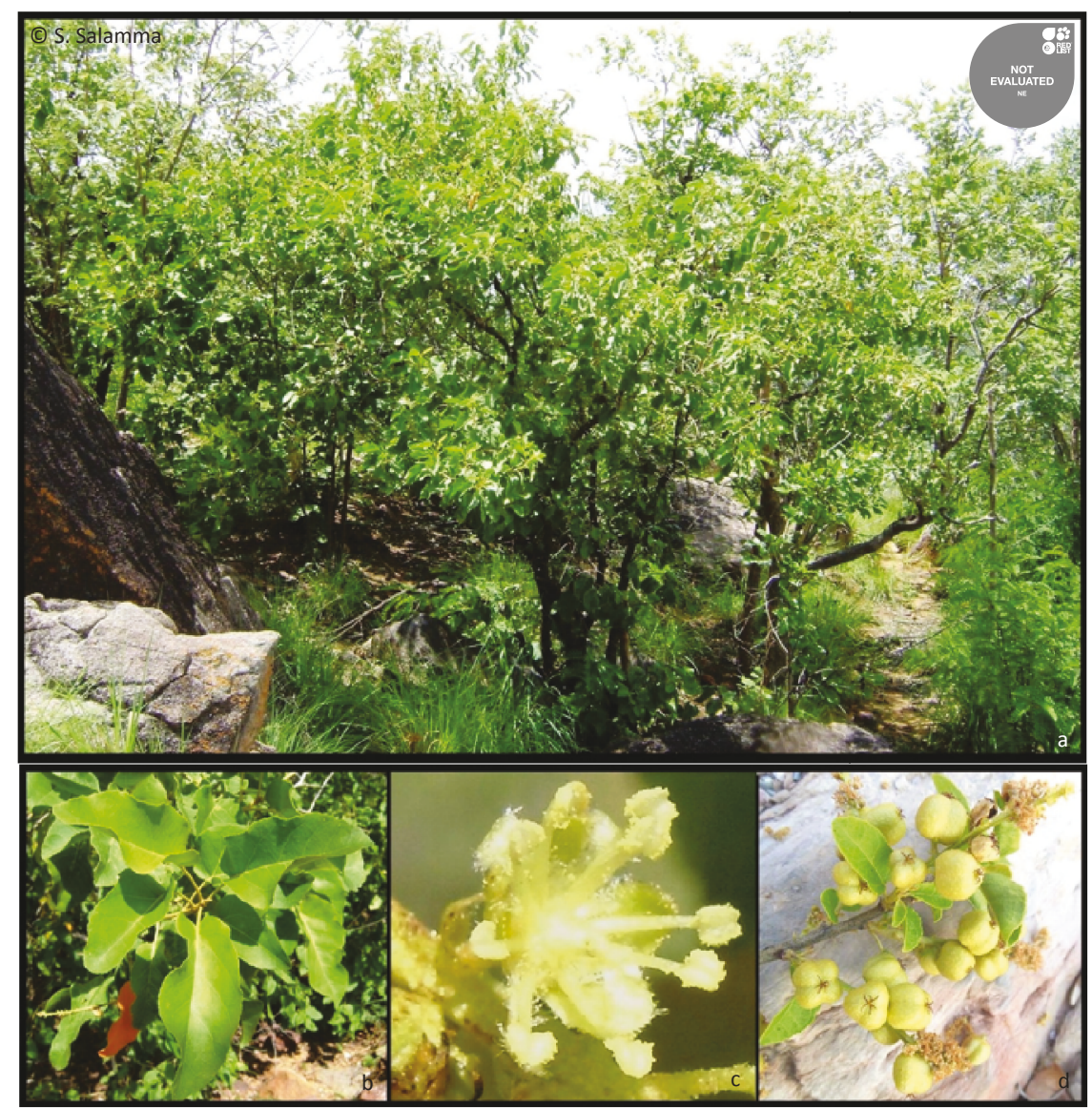

Image 1. Croton scabiosus.

a - Plants in Chinna Palle Hills, Anantapuram District; b - Foliage; c - Flower; d - Fruits

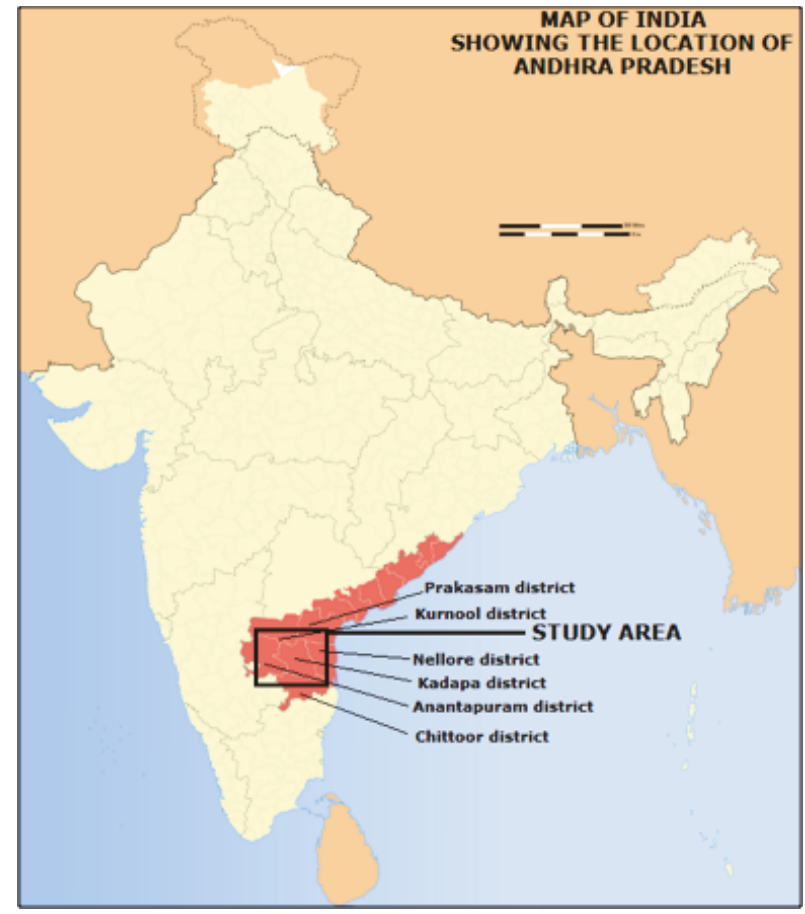

Image 2. Map of India showing Andhra Pradesh and study area eight locations (representing eight sub-populations) (Table 1). Of the eight locations, one location is recognized with four clusters (20 transects) and four locations with two clusters each (40 transects) and three locations with one cluster. Transects were laid with the help of a measuring tape, nails and nylon rope. All these transects were registered with geographical coordinates which are pointed on geo-reference satellite imagery gridded map. Resourcesat-2 geo-referenced imagery covering southern Andhra Pradesh is used for mapping the population, and grids of $4 \mathrm{~km}^{2}$ are stratified on the imagery. All the five transects in each location and projected area for species occurrence adjoining transects are encircled in the map.

\section{Determining the conservation status of the species}

With respect to conservation status, Croton scabiosus was categorized rare or threatened by Ahmedullah \& Nayar (1986) and 'indeterminate' by Rao et al. (2003). To ascertain the precise status, the present study evaluated the current 'conservation status' of the species based on 
Table 1. Locations and sampled transect clusters of Croton scabiosus

\begin{tabular}{|c|c|}
\hline Nomenclature of Location/ Cluster & Elevation (in $\mathrm{m}$ ) \\
\hline \multicolumn{2}{|c|}{ L1. Chinna Palle (Anantapuram \& Kadapa districts) } \\
\hline Cluster 1: Chinnapalle Hills & $489-702$ \\
\hline Cluster 2: KK Kottala Hills & $389-524$ \\
\hline Cluster 3: Rachakuntapalli forest & $378-466$ \\
\hline Cluster 4 :Tummalapalli Mining area & $430-511$ \\
\hline $\begin{array}{l}\text { L2. Vempalli (Kadapa District) } \\
\text { Cluster: Vempalli Hills }\end{array}$ & $382-486$ \\
\hline \multicolumn{2}{|l|}{ L3. Guvvalacheruvu (Kadapa District) } \\
\hline Cluster 1: Guvvalacheruvu Hills & $458-537$ \\
\hline Cluster 2: Palakondaraya Hills & $185-265$ \\
\hline \multicolumn{2}{|l|}{ L4. Lankamalleswaram (Kadapa District) } \\
\hline Cluster 1: Lankamala forest & $425-574$ \\
\hline Cluster 2: Nithyapuja Kona & $452-502$ \\
\hline \multicolumn{2}{|l|}{ L5. Gandikota (Kadapa District) } \\
\hline Cluster 1: Gandikota Hills & $382-494$ \\
\hline Cluster 2: Mangapatnam Hills & $333-387$ \\
\hline $\begin{array}{l}\text { L6. Sanipaya (Kadapa District) } \\
\text { Cluster: Sanipaya hills }\end{array}$ & $576-720$ \\
\hline $\begin{array}{l}\text { L7. Chitvel-rapur (Kadapa \& Nellore District) } \\
\text { Cluster: Chitvel-Rapur hills }\end{array}$ & $398-452$ \\
\hline \multicolumn{2}{|l|}{ L8. Udayagiri (Nellore District) } \\
\hline Cluster 1:Pandrangi forest-1 & $287-346$ \\
\hline Cluster 2:Pandrangi forest-2 & $412-512$ \\
\hline
\end{tabular}

observed and estimated data by following 3.1. version of IUCN Red List categories and Criteria (IUCN 2001) and guidelines as formulated in the IUCN version 11.0 (IUCN Standards and Petitions Subcommittee 2014). Accordingly, there are three threatened categories: Critically Endangered, (CR) Endangered (EN) and Vulnerable (VU) and five criteria (A-E) are used to assess the threatened status (Appendix 1). Meeting any one of the criteria is enough to categorize the species under any one of the threat categories. The five criteria are (A) population reduction; (B) area of distribution (C) and (D) population size and (E) probability of extinction in the wild. In the present study only B, C and D criteria are applied to determine the conservation status of the species as ' $A$ and $E$ ' require long-term observations.

The $B$ criterion-Area of distribution has been designed to identify populations with restricted distributions and which are fragmented or in decline. $B$ is measured as two estimates-the EOO (B1) and $A O O$ (B2). B1, extent of occurrence (EOO) is the area contained within the shortest continuous imaginary boundary, which can be drawn to encompass all the known, inferred or projected sites of the present occurrence of a taxon. The easiest measure for EOO is the area within a minimum convex polygon. For the purpose of measuring $\mathrm{EOO}$ and $\mathrm{AOO}$, satellite imagery of Resourcesat- 2 stratified with $4 \mathrm{~km}^{2}$ grids are used, as recommended by IUCN (IUCN Standards and Petitions Subcommittee 2014). All the grids and parts thereof covering species distribution regimes are counted and the total area is calculated. B2, area of occupancy (AOO) is defined as the area within its extent of occurrence, which is occupied by the taxon, excluding cases of vagrancy. The measure reflects the fact that a taxon will not usually occur throughout the area of its EOO, which may contain unsuitable or unoccupied habitats.

\section{RESULTS AND DISCUSSION}

\section{Distribution pattern of Croton scabiosus}

The distribution range of Croton scabiosus is highly misinterpreted by various floristic workers who have treated this species in their works. Beddome (1872) described the species based on his collections from 'Nullay Mallay' hills, Kurnool District. He cited the species occurrence as 'most abundant about the Yerrachalma (2000-3000 feet elevation)'. All the floristic studies pertaining to the Nallamalais after Beddome's report including that of Gamble (1925), Ellis (1990), Raju \& Pullaiah (1995), Sunitha (2002), Saheb (2008), Basha (2009) and Rao (2011) have not recorded its occurrence from the Nallamalais. Intensive sampling of 'whole Nallamalais' through $40 \mathrm{~km}^{2}$ grids in DBT sponsored project for 3.6 year period (Rao 2009) has only revealed its absence in the Nallamalais. It is significant to note that excepting Beddome's collection, no other collection from the present day Nallamalais is found in any local, regional, national or international herbaria. Hence, 'Nullay Mallay Mountains, Kurnool District' as cited by Beddome can be interpreted as the area covering 'Lankamalleswaram forests' where the species is discovered in abundance. This observation is further supported by 'contiguous intact forest patch' traversing northern Kadapa and the southern part of the Nallamalais of Kurnool District without any biotic interference 150 years back as visualized in the maps of Bartholomew (1907-1909).

About $80 \%$ of Croton scabiosus's habitat is found in Kadapa District. As inferred above, the collection sites of Beddome also fall within the present day Kadapa District boundaries. Recently, Banjamin \& Murthy (2013) reported the species from the Sanipayi area of Kadapa District. Records of S.K. Wagh cited by Babu (1997) indicating Thummalabailu locality, Anantapuram 
District and Suryanarayana \& Rao (2002) indicating the Penchalakona area of Nellore District do not match with our field observations which has been confirmed with the latter author. It is interesting to note that earlier records indicate that the species was distributed in the evergreen forests of the southern Western Ghats (Hooker 1890; Bourdillon 1908; Rao, 1914) and Courtallam in Tamil Nadu (Dhar et al. 1974). An intensive literature survey and consultations with various herbaria have revealed that there is not a single specimen collected or recorded either from Travancore (Kerala) or Tamil Nadu. Further discussion with Dr. A.K. Pradeep, renowned taxonomist from Calicut University, Kerala revealed that the distribution of Croton scabiosus in these areas is cited incorrectly. Balakrishnan \& Chakrabarty (2007) and the most recent Flora of India (Balakrishnan et al. 2012) also treated the species as endemic to Andhra Pradesh. Contrary to earlier publications which indicated the elevation range as 600-1300 m, our field observations revealed its presence in the elevation range of $200-700$ m.

In the present work, the occurrence of Croton scabiosus is recorded from the six localities, viz.,
Pandrangi forest near Udayagiri in Nellore District, Mangapatnam and Gandikota, Rachakuntapalli, Thummalapalii and Lankamalleswaram in Kadapa District in addition to the already reported areas of distribution in these two districts. Ambiguity in interpreting the names of the correct distributional localities of Croton scabiosus cited in the earlier works is now resolved during the present studies. In conclusion, our field observations, literature survey, consultations with national and regional herbaria have revealed that 'Croton scabiosus' is a strict endemic to the deciduous forests of southern Andhra Pradesh.

\section{Conservation status of the species}

Croton scabiosus confined to a small geographical area on a global scale warrants an evaluation in terms of its conservation status. Further, with the population scattered and subjected to threats in terms of fire, habitat degradation as well as intrinsic factors like seed borne pathogens, it warrants such a study. Earlier works based on secondary data, categorized the species as rare or threatened (Ahmedullah \& Nayar 1986) and 'indeterminate' (Rao et al. 2003). This prompted us

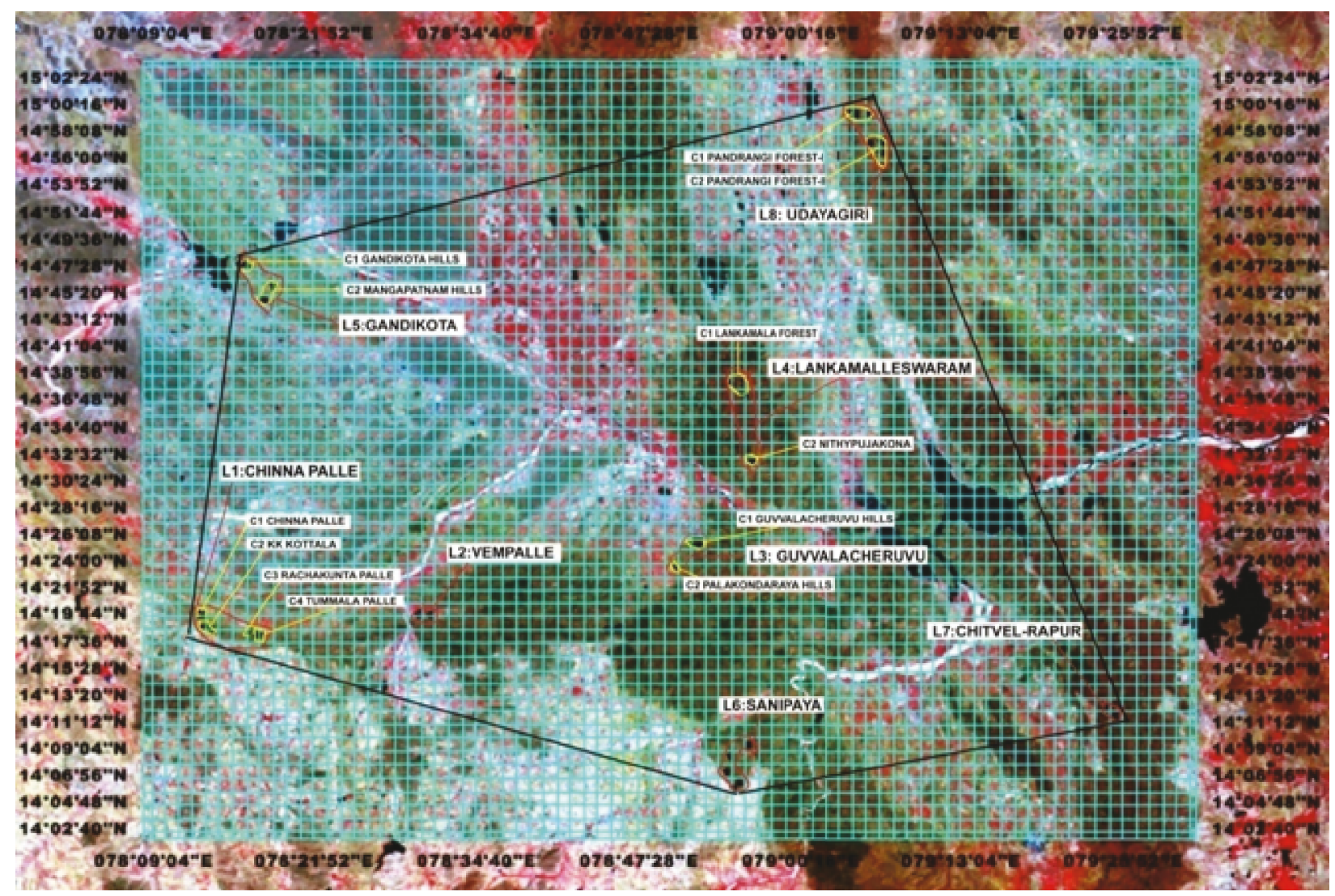

Image 3. Croton scabiosus: distribution sites and EOO/AOO map 
further to correctly evaluate the conservation status of the species based on authentic field data, following the latest version of IUCN Red List Categories and Criteria, 3.1 (IUCN 2001) and based on the guidelines as formulated in the IUCN Version 11.0 (IUCN Standards and Petitions Subcommittee 2014). The conservation status of Croton scabiosus has been assessed based on $B, C$ and $D$ criteria; criterion $B$ with reference to $B 1$ Extent of Occurrence (EOO) and B2 Area of Occupancy (AOO) is studied as follows:

Measurement of extent of occurrence (EOO): As presented earlier, all the 15 localities of species occurrence are grouped into eight locations based on threat factors following IUCN methodology (IUCN 2001). Each location is represented as a subpopulation and all the five transects in each locality made into one cluster is encircled. Eight locations are identified covering 1-4 transect clusters and are encircled. A minimum convex polygon was drawn with paint manager (Microsoft tool). All the grids within the polygon were carefully counted and the number of grids was multiplied with four (each grid is of $4 \mathrm{~km}^{2}$ size) to estimate the whole area in square kilometers. In calculations, the marginal grids of the polygon which were not fully covered in the polygon area were carefully measured. The final measurement is an approximation with 1-2 \% error. The EOO for Croton scabiosus is found to cover 2350 full grids (of $\left.4 \mathrm{~km}^{2}\right)$ and 32 half grids of $\left(2 \mathrm{~km}^{2}\right)$ and 56 one-fourth part of grids. The final measurement of EOO thus calculated is $9520 \mathrm{~km}^{2}$ (Image 3)

Measuring area of occupancy (AOO): All the 15 encircled cluster areas including observed and projected areas of species occurrence was measured on the grid map. It was found that the species has a patchy distribution within the grids, but whole grids were considered for measuring AOO owing to its possible presence in those habitats having similar terrain features like that of species in recorded areas around. The total AOO of C. scabiosus is calculated to about 690 hectares $\left(6.9 \mathrm{~km}^{2}\right)$ (Table 2)

Estimation of population size: The overall population size of the species was estimated by extrapolating the number of mature individuals counted for each cluster (five transects of 2.5ha area) and finally added up for the whole AOO (Table 1). The measurement of the population size with reference to AOO is based only on species occurrence in clusters, but not for a location where more than one cluster of individuals is recognized. The total number of mature individuals was thus calculated as 9400 for all the 15 clusters (equaling 37.5ha). This number is extrapolated for the total AOO $\left(690\right.$ hectares or $\left.6.9 \mathrm{~km}^{2}\right)$ of the species. Thus, a total of 173,590 mature individuals are estimated to survive in a $6.9 \mathrm{~km}^{2}$ area.

Table 2. Estimated population size of Croton scabiosus

\begin{tabular}{|c|c|c|c|c|c|}
\hline District & Location/Cluster & $\begin{array}{l}\text { Sampled area } \\
\text { (in ha) }\end{array}$ & $\begin{array}{l}\text { No. of mature individuals } \\
\text { In cluster ( } 2.5 \mathrm{ha} \text { ) }\end{array}$ & $\begin{array}{l}\text { Projected } \\
\text { AOO (in ha) }\end{array}$ & $\begin{array}{l}\text { Extrapolated no. of } \\
\text { individuals }\end{array}$ \\
\hline \multirow{4}{*}{$\begin{array}{l}\text { Ananatapuram/ } \\
\text { Kadapa }\end{array}$} & L1C1(ATP) & 2.5 & 870 & 20 & 6960 \\
\hline & L1C2(KDP) & 2.5 & 524 & 40 & 8384 \\
\hline & L1C3(KDP) & 2.5 & 487 & 50 & 9740 \\
\hline & L1C4(KDP) & 2.5 & 452 & 50 & 9040 \\
\hline \multirow[t]{9}{*}{ Kadapa } & L2 & 2.5 & 508 & 20 & 4064 \\
\hline & L3C1 & 2.5 & 539 & 50 & 10780 \\
\hline & L3C2 & 2.5 & 731 & 30 & 8772 \\
\hline & L4C1 & 2.5 & 660 & 50 & 13200 \\
\hline & L4C2 & 2.5 & 334 & 50 & 6640 \\
\hline & L5C1 & 2.5 & 225 & 50 & 4500 \\
\hline & L5C2 & 2.5 & 383 & 25 & 3830 \\
\hline & L6 & 2.5 & 1243 & 100 & 49720 \\
\hline & L7 & 2.5 & 546 & 25 & 5460 \\
\hline \multirow[t]{3}{*}{ Nellore } & L8C1 & 2.5 & 650 & 80 & 20800 \\
\hline & L8C24 & 2.5 & 585 & 50 & 11700 \\
\hline & Total & 37.5 & 8,737 & 690 & $1,73,590$ \\
\hline
\end{tabular}




\section{Application of IUCN criteria to 'Croton scabiosus'}

Criterion A: As the study requires long-term observations this criterion is not applied for assessment.

Criterion B: Pertains to two sub-criteria of geographic range of the population distribution, i.e., B1, the EOO and $B 2$, the $A O O$.

Sub-criterion B1: The EOO of the species is estimated at $9520 \mathrm{~km}^{2}$ (Image 3 ). Of the three conditions to be fulfilled under B1, the species was found to qualify for two. The species is restricted to eight locations; continuing decline observed in extent, quality of habitat and number of mature individuals. In conclusion, Croton scabiosus is categorized as 'Vulnerable' qualifying for B1ab(iii,v).

Sub-criterion B2: Based on the same qualifiers as above, Croton scabiosus meets the Vulnerable category according to its highly restricted $A O O$ of $6.9 \mathrm{~km}^{2}$.

Criterion C: Population size and decline. The total estimated population size of 173,590 mature individuals does not qualiffy the species under this criterion.

Criterion D: Given the high numbers of mature individuals, it does not qualify for this criterion.

Criterion E: Quantitative analysis estimating probability of extinction in the wild.

As the study requires long-term observations this criterion is not applied for the species.

Based on field observations and grid-based sampled analysis and application of IUCN Red List criteria, Croton scabiosus is categorized and given conservation status as 'Vulnerable' B1ab(iii,v)+B2ab(iii,v).

\section{REFERENCES}

Ahmedullah, M. \& M.P. Nayar (1986). Endemic Plants of India Region. Vol.1 (Peninsular India) Botanical Survey of India. Calcutta. 262pp.

Ahrends, A., C. Rahbek, M.T. Bulling, N.D. Burgess, P.J. Platts, J.C Lovett, V.W. Kindemba, N. Owen, A.N. Sallu, A.R. Marshall, B. E. Mhoro, E. Fanning \& R. Marchant (2011). Conservation and the botanist effect. Biological Conservation 144: 131-140; http:// dx.doi.org/10.1016/j.biocon.2010.08.008

Babu, P.S.P. (1997). Euphorbiaceae. In: Pullaiah, T. \& D.A. Moulal (ed.). Flora of Andhra Pradesh, India - Vol. 2. Scientific Publishers, Jodhpur, 836-890pp.

Balakrishnan, N.P. \& T. Chakrabarty (2007). The Family Euphorbiaceae in India. Bishen Singh Mahendra Pal Singh, Dehra Dun, 215pp.

Balakrishnan, N.P., T. Chakrabarty, M. Sanjappa, P. Lakshminarasimhan \& P. Singh (eds.) (2012). Croton scabiosus, pp. $240-242$, fig. 36. In: Flora of India - Vol. 23. Botanical Survey of India, Kolkata.

Bartholomew, J.G. (1907-1909). Madras (Southern section) with Mysore, Coorg, and Travancore. In: Imperial Gazetteer of India. New edition, published under the authority of His Majesty's Secretary of State for India in Council - Vol. 18. Clarendon Press, Oxford, opposite page 250 .

Basha, S.K. (2009). Diversity, Quantification and Conservation of
Tree Resources of Nallamalais, Andhra Pradesh. PhD Thesis, Sri Krishnadevaraya University, Anantapur.

Beddome, R.H. (1872). The Flora Sylvatica for Southern India. Gantz Brothers, Madras, 283pp+pls-CCLXXXIII.

Banjamin, J.H.F. \& G.V.S. Murthy (2013). Flora of Sri Venkateswara National Park, Andhra Pradesh. Botanical Survey of India, Kolkata, $492 \mathrm{pp}$

Bourdillon (1908). The Forest Trees of Travancore. The Travancore Government Press, Trivandrum, 456pp.

Caro, T.M. (1998). Behavioral Ecology and Conservation Biology. Oxford University Press, New York, 608pp.

Dhar, M.L., B.N. Dhawan, C.R. Prasad, R.P. Rastogi, K.K.Singh \& J.S. Tandon (1974). Screening of Indian plants for biological activity part V. Indian Journal of Experimental Biology 12: 512-523.

Ellis, J.L. (1990). Euphorbiaceae, pp. 406-417. In: Flora of Nallamalais - Vol. 2. Flora of India Ser. 3. Botanical Survey of India, Calcutta.

Gamble, J.S. (1925). Flora of the Presidency of Madras - Vol. 2. West Newman and Co., Adlard \& Sons, London, 1314pp. (Reprint ed. 2: 934, 1957), Bishen Singh Mahendra Pal Singh, Dehra Dun.

Hagihara, A., S.M. Feroz \& M. Yokota (2008). Canopy multi layering and woody species diversity of subtropical evergreen broadleaf forest, Okinawa Island. Pacific Science 62(3): 363-376.

Hooker, J.D. (1890). The Flora of British India - Vol. 5. Reeve \& Co. London, 386pp.

IUCN (2001). Species Survival Commission, IUCN Red List Categories, Version

3.1.<http:///www.iucn.org/themes/ssc/red lists/ssc-rl-c.htm

IUCN (2014). The IUCN Red List of Threatened Species. Version 2014.1 <http://www.iucnredlist.org>. Accessed August 1, 2014.

IUCN Standards \& Petitions Subcommittee (2014). Guidelines for using the IUCN Red List Categories and Criteria. Version11. Prepared by standards \& petitions subcommittee Downloadable from <http:// www.iucnredlist.org.documents/Red List Guidelines.pdf.

Miller, S.J., G.A. Krupnick, H. Stevens, H.P. Morgan, B. Boom, P.A. Rodríguez, J. Ackerman, D. Kolterman, E. Santiago, C. Torres \& J. Velez (2013). Towards Target 2 of the global strategy for plant conservation: an expert analysis of the Puerto Rican flora to validate New Streamlined methods for assessing conservation status. Annals of the Missouri Botanic Garden 99(2): 199-205; http://dx.doi. org/10.3417/2011121

Nayar, M.P. \& A.R.K. Sastry (1987). Red Data Book of Indian Plants Vol. 1. Botanical Survey of India, Calcutta.

Nayar, M.P. \& A.R.K. Sastry (1990). Red Data Book of Indian Plants Vol. 2 \& 3. Botanical Survey of India, Calcutta.

Rao, B.R.P. (2009). Final report on the multi-institutional project 'Quantitative Assessment and Mapping of Plant Resources in Eastern Ghats. Submitted to Department of Biotechnology, Govt. of India. New Delhi.

Rao, B.R.P., M.V.S. Babu \& J. Donaldson (2010). A reassessment of the conservation status of Cycas beddomei Dyer (Cycadaceae), an endemic of Tirupati-Kadapa Hills, Andhra Pradesh, India, and comments on its CITES status. Encephalartos 102: 19-24.

Rao, B.R.P., M.V.S. Babu, A.M. Reddy, S. Sunitha, A. Narayanaswamy, G. Lakshminarayana \& M. Ahmedullah (2011). Conservation status of Hildegardia populifolia (Roxb.) Schott \& Endl. (Malvaceae: Sterculioideae: Sterculiaceae), an endemic of southern peninsular India. Journal of Threatened Taxa 3(8): 2018-2022; http://dx.doi. org/10.11609/JoTT.o2733.2018-22

Rao, B.R.P., K. Prasad, M. Bheemalingappa, M.C. Naik, K.N. Ganeshaiah \& M. Sanjappa (2012). Conservation status of Dendrobium tenuicaule Hook. f. (Orchidaceae), a middle Andaman Island endemic, India. Journal of Threatened Taxa 4(15): 34103414; http://dx.doi.org/10.11609/JoTT.o3186.3410-4

Rao, C.K., B.L. Geetha \& G. Suresh (2003). Red list of Threatened Vascular Plant Species in India. Botanical Survey of India. Kolkata, $129 p p$.

Rao, M.R. (1914). Flowering plants of Travancore. Government Press, Trivandrum.

Raju, R.R.V. \& T. Pullaiah (1995). Flora of Kurnool (Andhra Pradesh). 
Bishen Singh Mahendra Pal Singh. Dehra Dun, 412pp.

Rao, V.S. (2011). Carbon Sequestration Potential of Tropical Deciduous Forests of Nallamalais, Andhra Pradesh, India. PhD Thesis, Sri Krishnadevaraya University, Anantapur. Andhra Pradesh, India.

Secretariat of the Convention on Biological Diversity (2010). Global Biodiversity Outlook 3. Montreal.

Saheb, T.S. (2008). Medicinal Plant Resources and Conservation in Nallamalais, Andhra Pradesh. PhD Thesis. Sri Krishnadevaraya University, Anantapur.

Sunitha, S. (2002). Plant Biodiversity of the Sacred Groves of Kurnool District, Andhra Pradesh. PhD Thesis, Sri Krishnadevaraya University, Anantapur, India.

Suryanarayana, B. \& A.S. Rao (2002). Flora of Nellore District, Andhra Pradesh. Gurudev Prakashan, Shrimapur, Maharashtra, 478pp.

Umashaanker, R., K.N. Ganeshaiah, K.S. Murali \& K.S. Bawa (1998). Mapping of Biological Richness of BR Hills, pp. 9-11. In: Ganeshaiah, K.N., R. Umashaanker \& K.S. Bawa (eds.). Biligiri Rangaswamy Temple Wildlife Sanctuary: Natural History, Biodiversity Conservation. ATREE and GKVK, Bangalore.

Vischi, N., E. Natale \& C. Villamil (2004). Six endemic plants species from central Argentina: an evaluation of their conservation status. Biodiversity Conservation 13: 997-1008; http://dx.doi.org/10.1023/ B:BIOC.0000014465.31740.9b 